PRZEGLĄD NAUK HISTORYCZNYCH 2016, R. XV, NR 2

http://dx.doi.org/10.18778/1644-857X.15.02.08

DROBNE PRACE I MATERIAEY

Adam Elbanowski

UNIWERSYTET WARSZAWSKI"

\title{
Przypadki niemieckiego odkrywcy i konkwistadora Philippa von Hutten, zwanego Felipe de Utre
}

mbrosio Alfinger (Ambrosius Ehinger), Felipe de Utre (Philipp
von Hutten), Jorge de Espira (Georg Hohermuth), Nicolás
de Federmann (Nikolaus Federmann) - w pierwszej połowie XVI w. to właśnie ci czterej niemieccy odkrywcy i konkwistadorzy zapoczatkowali dzieje Wenezueli. Ich losy - a wszyscy czworo związani byli $z$ domem bankowym Welserów ${ }^{1}$ i zarządzali ta prowincją - potoczyły się w duchu tragicznej ironii. Wszyscy czterej szukali Eldorado i nigdy go nie znaleźli. Alfinger zginął w 1533 r. od indiańskiej strzały na bezdrożach Chinácota, na dzisiejszym pograniczu kolumbijsko-wenezuelskim. Felipe de Utre 13 lat później od katowskiego miecza opodal miasta El Tocuyo w Wenezueli. Jorge de Espira nie dostał zgody na powrót do Europy; zmuszono go do osiedlenia się w Coro, gdzie schorowany spędził ostatnie lata życia, by nigdy więcej nie wyruszyć do wymarzonego Eldorado. Tylko Federmann wrócił do Europy, aby trafić do więzienia, $z$ oskarżenia Welserów o malwersacje i nadużycia popełnione w Wenezueli.

Niemcy nie budzili sympatii Hiszpanów w Wenezueli, ponieważ ci „perfidni heretycy” ${ }^{2}$ sprawowali tam bezwzględne rządy i wszystkie

*Wydział Lingwistyki Stosowanej, Instytut Kulturologii i Lingwistyki Antropocentrycznej.

${ }^{1}$ Karol V, mając znaczne długi wobec domu bankierskiego Welserów, oddał im w latach 1528-1546 w dzierżawę Wenezuelę i zezwolił na eksploatowanie wszelkich bogactw tej prowincji.

${ }^{2}$ P. Si món, Noticias historiales de las conquistas de Tierra Firme en las Indias Occidentales, cz. 1, Bogota 1882, s. 2. 
łupy zagarniali dla siebie. Ale Philipp von Hutten, zwany przez nich Felipe de Utre, był inny od swych rodaków. $Z$ jego twarzy widać było arystokratyczne pochodzenie, a odwaga, opanowanie i rozwaga mimo młodego wieku budziły zaufanie wśród żołnierzy. Zapewne i ujmująca powierzchowność - kasztanowe włosy, wysokie czoło, niewielka, hiszpańska bródka, brązowe oczy, lekko odstające, wachlarzowate uszy - przysporzyła mu sympatii. Musiał przerażać go ten ogromny, dziki kraj i prymitywne, drewniane chaty, w których przyszło mieszkać młodemu junkrowi, w niczym nieprzypominajace dworu Karola V, który poznał jako dziecko. W listach wysyłanych $z$ Coro do ojca i brata skarżył się na swój los, nie ukrywając, że Wenezuela nie przyniosła mu ani szczęścia, ani fortuny. A przecież to nie tylko wizja łupów i bogactw zachęciła go do wyprawy do Nowego Świata, ale ciekawość owego świata. Do swego ojca pisał: „Bóg mi świadkiem, że to nie żądza fortuny skłoniła mnie do tej podróży, ale owo osobliwe pragnienie, tkwiące we mnie od dawna, i mniemam, że nie umarłbym w spokoju ducha, gdybym nie zobaczył Indii [...]"3.

Nawet nie zdobył zaszczytnego tytułu gubernatora Wenezueli, czego oczekiwał po śmierci Jorge de Espira w 1540 r. - wypominano mu młody wiek i brak doświadczenia - i musiał się zadowolić tytułem naczelnego dowódcy (capitan general). Widocznie miał jakieś przeczucie śmierci, jakby przewidział starcie $z$ kapitanem Juanem de Carvajal, bo sześć lat wcześniej w liście do brata Wilhelma napisał: „bardziej lękam się wojny z chrześcijanami niż z Indianami”4.

Królewski kronikarz Fernández de Oviedo, choć nie poświęcił mu wiele miejsca w swej monumentalnej kronice ${ }^{5}$, pisał o nim ciepło: „niemiecki rycerz, człowiek szlachetny i wartościowy”, a nieco

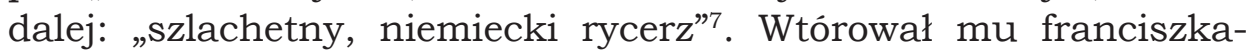
nin Pedro Simón: „młodzieniec niewiele lat liczący, ale obdarzony

3 Cyt. za: Alemanes en las regiones equinocciales, wyd. J. Ángel Rodríguez, Caracas 1999, s. 47.

${ }^{4}$ Cyt. za: G. Arciniegas, Felipe von Hutten, o la ilusión de 'El Dorado', [w:] i d e m, América, tierra firme y otros ensayos, Caracas 1990, s. 296.

5 Wyprawom Niemców w Wenezueli poświęcił Fernandez de Oviedo jedna $z$ ksiag swej kroniki: F. de Oviedo, Historia general y natural de las Indias, islas y tierra-firme del mar océano, Tomo primero de la segunda parte, segundo de la obra, ks. XXV, rozdz. 1-22, s. 269-331; Imprenta de la Real Academia de la Historia, Madrid 1852.

${ }^{6}$ Ibidem, rozdz. 20, s. 324.

${ }^{7}$ Ibidem, rozdz. 21, s. 325. 
dojrzałą rozwaga i ostrożnościa, energiczny i biegły w sprawach wojny i wypraw [...]”8. José Oviedo y Baños pisał zaś, że „był Utre łagodny i prostoduszny”, ale co ważniejsze: „żaden z kapitanów walczacych w owych Indiach mniej nie zbroczył krwia swego rapieru" ${ }^{10}$. Wymowne, że w „tajnym dochodzeniu przeciwko Niemcom z Wenezueli" - długiej liście zbrodni i nadużyć popełnionych przez niemieckich dowódców - pośród 46 zarzutów nazwisko Felipe de Utre się nie pojawiło ${ }^{11}$.

$$
* * *
$$

Największa wyprawa Felipe de Utre odbyła się w latach 1541-1546 ${ }^{12}$. Ekspedycja licząca 130 żołnierzy wyruszyła $z$ Coro w czerwcu 1541 r. Wzięli w niej udział czterej dowódcy: Bartolomé Welser (wielka nadzieja bankierskiego rodu Welserów, zwłaszcza swego ojca), Sebastián de Amescua, Martín de Artiaga oraz chorąży (maestre de campo) Pedro de Limpias. Gdy dotarli do osady Nuestra Señora, trafili na ślady swoich poprzedników. Jorge de Espira był tu cztery lata wcześniej i to on nadal imię osadzie, które potem jego bardziej praktyczny rodak, Nicolás Federmann, przemianował

${ }^{8}$ P. Simón, Noticias historiales de Venezuela, t. II, Caracas 1992, s. 11.

${ }^{9} \mathrm{~J}$. de Ovie do y Baños, Historia de la conquista y población de la Provincia de Venezuela, Caracas 2004, s. 137.

${ }^{10}$ Ibidem, s. 139.

${ }^{11}$ Interrogatorio de testigos para la pesquisa secreta contra los Alemanes de Venezuela, [w:] Historia de la conquista y población de la provincia de Venezuela escrita por Dr. José de Oviedo y Baños, t. II, Madrid 1885, s. 259-276.

${ }^{12}$ Wykorzystałem następujace kroniki: P. de Aguado, Historia de Venezuela, t. I, ks. III (s. 109-262), Madrid 1918; J. de Castella nos, A la muee del gobernador Felipe de Uten, donde se cuenta la entrada que hizo y cosas en ella acontecidas, [w:] Elegias de varones ilustres de Indias (Obras de Juan de Castellanos, t. I, cz. II, elegia III, s. 328-362), P.L. Hermanos, Editorial Sur América, Caracas 1930; P. Simón, Noticias historiales de Venezuela, t. II, rozdz. 1-11 (s. 11-50); L.F. de Piedrahita, Historia general de las conquistas del Nuevo Reyno de Granada, ks. X, rozdz. 5 (s. 412-419), Amberes 1688; J. de Oviedo y Baños, Historia de la conquista y población de la Provincia de Venezuela, ks. II, rozdz. 11-13 i ks. III, rozdz. 1-3 (s. 107-142). Ponadto siegnąłem po dokumenty opublikowane w aneksie do Historia de la conquista y población de la provincia de Venezuela escrita por Dr. José de Oviedo y Baños, t. II (Relación de diferentes Gobernadores nombrados con destino á Venezuela desde 1530 á 1555, con expresión de sus principales hechos), s. 215-218; Cartas dirigidas al Rey por el Licenciado Juan Pérez de Tolosa, con noticia de ocurrencias y descripción del territorio de su gobernación, s. 219-224; Interrogatorio de testigos..., s. 259-276; Real cédula mandando hacer justicia contra los que fueron en la muerte de Felipe de Huten y de Bartolomé Belzar, s. 277-280. 
na Nuestra Señora de la Fragua - Kuźnia - tam bowiem żołnierze zorganizowali kuźnię polową, by podkuć swoje konie. W przyszłości powstanie tu miasto San Juan de los Llanos.

W Nuestra Señora dowódcy wyprawy dowiedzieli się, że przed nimi ziemie te przemierzył niedawno brat Jiménez de Quesada - zdobywcy Nowej Grenady - Hernán Pérez. Felipe de Utre postanowił iść śladami Hiszpana, mimo że jakiś Indianin namawiał go, by zawrócił ku miastu zwanym Matacoa, słynącemu $z$ ogromnych bogactw. Trwała zima, padały niekończące się deszcze, a równiny zamieniały się w bezkresne rozlewiska. Na próżno Niemiec wypatrywał dalszych śladów Hernána Péreza. Gdy wreszcie skończyła się pora deszczowa, poszedł za radą owego tubylca. Zostawił pod eskortą rannych i zmienił kierunek marszu, idac $z$ kapitanem Pedro de Limpias i 40 żołnierzami do Matacoa. Dalej bowiem rozciagała się kraina Omeguas, gdzie znajdowało się Eldorado. Przekroczyli rzekę Guaviare i dotarli do Matacoa, gdzie zawiązali sojusz z miejscowym kacykiem. Spędzili tu pięć dni. Zbliżał się koniec roku 1543. Kacyk Matacoa zapewniał Niemca, że lud Omeguas ma zwierzęta podobne wielkim owcom czy też baranom, których może dosiadać, tak jak Hiszpanie dosiadaja koni, co tylko przekonało Utre, że są blisko Peru, bo zapewne kacyk miał na myśli lamy.

Matacoa zrobiło na nich duże wrażenie. Była to wielka, licząca 800 mieszkańców osada, stolica prowincji o takiej samej nazwie, położona nad brzegiem Guaviare, dopływem Orinoko. Znajdowały się tam przestronne place, ogromne domostwa, ulice były czyste, bez jednego kamyczka czy trawy. Kacyk przestrzegł konkwistadorów, że są zbyt nieliczni, by ruszyć na ogromną i waleczną armię Omeguas. Felipe de Utre, niepomny ostrzeżeń, szedł dalej. Wędrował dziewięć dni $z$ przewodnikami indiańskimi, których ofiarował im kacyk Matacoa, a on sam $z$ setka wojowników towarzyszył Hiszpanom. Po pięciu dniach doszli do pierwszej osady Omeguas, liczącej 50 chat, która rządził kacyk Cuarica (Quarica). Ze wzgórza, na którym położona była osada - potem okazało się, że był to przysiółek zamieszkały przez strażników i zwiadowców, którzy pilnowali granic swojego kraju - obserwowali druga osadę, tak rozległa, że nie było widać jej końca, choć leżała opodal. Miała równe, proste ulice, ciasno stłoczone domy, a pośród nich wznosiła się ogromna budowla, przestronna i starannie wykonana. Kacyk-przewodnik wyjaśnił im, że to pałac władcy Cuarica, służący za jego siedzibę i świątynię, gdzie przechowywano liczne złote idole należące do 
niego i do jego poddanych. Były tam posagi o rozmiarach dziecka i inne - wyobrażajace kobiety, naturalnej wielkości i wiele innych kosztowności. Kacyk Matacoa, doprowadziwszy Hiszpanów do tego miejsca, zawrócił, informujacc, że dalej znajdują się jeszcze ludniejsze i bogatsze osady. Na pożegnanie doradził im, by pochwycili jako tłumacza kilku Indian $z$ owej wioski. Przestrzegł przed wojowniczym ludem Omeguas i radził pojmać tych Indian, którzy uciekajacc przed Hiszpanami, ukryli się w domach, ponieważ było bardziej niż pewne, że gdy minie pierwsze zagrożenie, uprzedza swoich pobratymców $z$ oddalonych wiosek o nadejściu Hiszpanów, a wówczas ci zastana osady bezludne, chaty puste, a magazyny żywności opróżnione. Taką bowiem taktykę stosowali tubylcy, a niejednokrotnie zdarzało się, że nim uciekli ze swojej wioski, puszczali ją z dymem, podobnie jak pola kukurydzy, aby głodem zmusić najeźdźców do opuszczenia ich ziem.

Kacyk Matacoa nieraz dawał dowody swej przyjaźni, czy to $z$ lęku przed przybyszami, czy to $z$ sympatii do Felipe de Utre, zatem Niemiec posłuchał go i wkroczył na czele swojego oddziału do osady. Żołnierze jednak nie zdołali nikogo pochwycić. Tylko Utre, który miał najbardziej chyżego konia, dopadł rosłego Indianina, który uciekał, dzierżąc w dłoni długą lancę. Widząc jednak, że nie uda mu się ujść przed jeźdźcem, odwrócił się w jego stronę i cisnął $z$ tak ogromna siła lancę, że przebiła ona pancerz Niemca i wbiła się głęboko pod prawe ramię. Dowódca zdołał wyrwać lancę ze swego boku i trzymając się kurczowo uzdy, zawrócił do swoich. Ci zaś stali opodal, w osłupieniu, niezdecydowani, czy wycofać się, czy ścigać uciekających Indian.

Dopiero wówczas dotarły do nich przestrogi kacyka, by nie drażnić ludu tak wojowniczego. Jakby na potwierdzenie tych obaw rozległ się ogłuszający łoskot bębnów, wysokich na pięć do sześciu varas $^{13}$, piszczałek i trąb wykonanych $z$ morskich muszli, jakby Omeguas chcieli wezwać wszystkich mieszkańców tej krainy, aby uderzyli na Hiszpanów. Tak się zreszta stało. Wycofali się konkwistadorzy noca, pospiesznie, niosac w hamaku ciężko rannego dowódcę, eskortowani przez indiańskich sojuszników. Odwrót trwał cała noc i dopiero nad ranem dotarli do Matacoa. Tam rannym zajał się Diego de Montés, rodem z Madrytu: „nie żeby był cyrulikiem albo chirurgiem, lecz dlatego, że próżno byłoby szukać kogoś, kto

${ }^{13}$ Hiszpańska miara długości: ok. $80 \mathrm{~cm}$. 
umiałby tyle co on"14. Diego de Montés zgłębiał tajniki medycyny, studiując anatomię na polu bitwy, a nadto, idąc w ślady tubylczych znachorów, poznawał zioła, nawary, okłady $-z$ tytoniu, żeniszku czy bezoaru - które tamci stosowali.

Diego de Montés bezradnie obejrzał ranę Niemca, ogromna, poszarpaną wyrwę w boku, między żebrami, nie widząc, czy pocisk sięgnął ponad komora serca, czy też ją naruszył. Zwrócił się do zaprzyjaźnionego kacyka o pomoc. Ten „wziął starego Indianina, już (jak można mniemać) znużonego życiem"15, i wsadził na konia, uprzednio nałożywszy nań hiszpańska zbroję. Potem jednemu $z$ rosłych wojowników ze swej gwardii przybocznej wsunał do ręki lancę, podobną do tych, których używali Omeguas, i nakazał cisnąć pocisk $z$ taką samą siłą i $z$ tej samej odległości dzielącej jeźdźca od miotacza, by grot wbił się dokładnie tam, gdzie trafił w ciało Felipe de Utre. „Próba, która nieszczęśnika kosztowała życie”"16, ułatwiła zadanie Diegowi de Montés. Mógł teraz uważnie przestudiować ranę, niczym na manekinie, usilnie starajac przypomnieć sobie budowę serca, łuk aorty, żyły i tętnice płucne, miejsce, gdzie znajdują się obie komory serca. Zanim medyk przystapił do zoperowania rannego dowódcy, sekcja trwała długo. Ostrym nożem otworzył ranę szerzej, za pomoca wywaru z drzewa arrayán starannie ją oczyścił i obmył z krwi. Kacyk i jego Indianie ze zdumieniem przyglądali się tym zabiegom i trudno powiedzieć, czy bardziej podziwiali odporność i hart ducha rannego Niemca, którego szlachtowano niczym wieprza, czy raczej uznali, że skoro przywódca Hiszpanów mężnie i bez skargi znosi ten zabieg, bez watpienia nawet tak nieliczna garstka, jak 40 żołnierzy, zdolna jest pokonać tysiące Omeguas.

Ci jednak, jak się później okazało, nie zamierzali ustępować $z$ pola walki. Podczas nocnego odwrotu Hiszpanów postępowali krok w krok za nimi, tak cicho i niepostrzeżenie, że ani tamci, ani ich indiańscy sprzymierzeńcy nie zorientowali się, że są niczym tropiona przez myśliwych zwierzyna. Dostrzeżono ich dopiero wtedy, gdy w sile 15 tysięcy wojowników podeszli na odległość dwóch ligit od wioski kacyka. Ten niezwłocznie powiadomił rannego dowódcę o zbliżającym się niebezpieczeństwie, ale Felipe de Utre, który leżał rozciagnięty $\mathrm{w}$ hamaku, osłabiony upływem krwi, nie był nawet

\footnotetext{
${ }^{14}$ L.F. de Piedrahita, op. cit., s. 414.

${ }^{15}$ P. Simón, Noticias historiales de Venezuela..., s. 36.

${ }^{16} \mathrm{~J}$. de Oviedo y Baños, op. cit., s. 129.

${ }^{17}$ Legua: od 5,572 do 5,914 km.
} 
w stanie dosiąść konia. Toteż przywołał do siebie kapitana Pedra de Limpias i powierzył mu dowództwo. Kapitan, praktyczny, doświadczony wojak o awanturniczym usposobieniu, ruszył na Omeguas, którzy zmierzali rozległą równiną w ich stronę, uformowani w równe szyki, niczym armia na polach pod Pawią. Dzierżyli w rękach długie lance $z$ pnia palmowego o ostrych, opalanych końcach i okragłe pawęże, strojni w pióropusze $z$ barwnych, powiewających na wietrze piór. Jeźdźcy zbili się w zwarta grupę, choć nie było ich wielu, za nimi ruszyła piechota hiszpańska pod dowództwem młodego Bartolomé Welsera i choć pierwszy impet Indianie przetrzymali, szarża Pedra de Limpias ostatecznie rozbiła ich szeregi. Ku zdumieniu Hiszpanów nie poszli jednak w rozsypkę, co niemal zawsze zdarzało się w takich potyczkach, ale wycofywali się zwartym szykiem. To tylko rozsierdziło konkwistadorów, którzy uderzyli z jeszcze większym impetem, jakby chcieli potwierdzić, że są niezwyciężeni, że pod naporem ich koni i stali żaden przeciwnik nie zdoła im się oprzeć. Dopiero ta ponowna, gwałtowna szarża rozbiła szeregi Omeguas, którzy przekonali się, że ich zaciekłość nie tyle osłabia przeciwnika, co budzi w nim jeszcze większą wolę walki. Wtedy rozpierzchli się na wszystkie strony, pozostawiajac trupy i rannych, a tymczasem po stronie Hiszpanów nie było prawie żadnych strat, $z$ wyjątkiem dość poważnej rany, jaka odniósł od lancy kapitan Martín de Artiaga. Ten sam, który w 1540 r. weźmie udział w fundacji Cartago w dolinie rzeki Cauca, w Nowym Królestwie Grenady i zostanie jednym $z$ pierwszych alkadów tego miasta.

Po krótkim odpoczynku, mając też na uwadze stan Felipe de Utre, Hiszpanie postanowili udać się do osady Nuestra Señora, aby przemyśleć dalszy plan podboju ziem Omeguas. Kacyk Matacoa za wszelka cenę usiłował odwlec ich wyjazd i trudno dociec, czy widząc siłę i skuteczność w walce, próbował zyskać ich przychylność, być może, snując plany własnych podbojów, mając przy sobie tak potężnych sojuszników, czy po prostu pragną przyjrzeć się bliżej obyczajom i strojom przybyszów, które wyraźnie przypadły mu do gustu. Widzą jednak determinację Hiszpanów, dał im prowiant i przewodników. Ruszyli najpierw w stronę Matacoa, prowadzeni przez indiańskich przewodników, ci jednak pewnego dnia uciekli, pozostawiając zdezorientowanych bezkresną równina Hiszpanów. Doszli do rzeki Guaviare i odnaleźli Matacoa, a potem ruszyli do Nuestra Señora, gdzie pozostawili rannych po trzech miesiącach, które minęły od ich wyjazdu. 
Wszyscy oni wierzyli, że gdzieś tam jest prowincja, ludna, bogata w złoto i srebro, o ziemiach żyznych pod uprawę i hodowlę bydła, a w końcu to rzecz nieistotna, czy należy zwać ją Aomaguas, Omaguas, Omeguas, a może Ditaguas. Żołnierze Felipe de Utre widzieli się władcami tej złotej krainy, niepomni, że chciwość, nienawiść i wygórowana ambicja nie sa dobrymi doradcami. Były wreszcie niesnaski, o które nietrudno w tak małej grupie ludzi, którzy miesiącami i latami dzielili trudy wyprawy po bezdrożach, leżeli w hamakach, ramię w ramię, jedli $z$ tego samego kotła, zawistnie patrzyli sobie na ręce, czy aby kompan nie zdobył kosztowniejszego łupu. Zły przykład dawali dowódcy, kapitanowie Pedro de Limpias i Bartolomé Welser, którzy nie kryli wzajemnej niechęci, wynikającej nie tyle $z$ różnicy charakteru i pozycji społecznej, co osobliwej animozji, jaka zrodziła się między Kantabryjczykiem a Augsburgczykiem, a $z$ takiego połaczenia nigdy nic dobrego nie wynika. Niewykluczone jednak, że powodem konfliktu był podział łupów zdobytych w osadach Omeguas. Bartolomé miał wkrótce dokonać żywota, w maju 1546 r., ścięty, wraz z Felipe de Utre, z rozkazu kapitana Juana de Carvajal. Na nic zdały się próby Felipe de Utre, by pogodzić obu kapitanów, choć $z$ oczywistych powodów nie był on do końca bezstronny. Ogromna ceiba opodal E1 Tocuyo, która Juan de Carvajal upatrzył sobie jako miejsce kaźni dla swoich wrogów, stała się szubienica dla niego samego w czerwcu 1546 r.

Utre postanowił wysłać z Nuestra Señora Bartolomé Welsera z grupa 20 żołnierzy do Coro po posiłki. Dotarli, podążając tą samą droga co przedtem, do prowincji El Tocuyo i Barquisimeto. Tam Pedro de Limpias namówił Juana de Carvajal, by przejął dowództwo nad siłami, które przywiódł z Coro - 50 konnych - i na własną rękę, wbrew Felipe de Utre, zdobył prowincje Omeguas. Niemiec domyślił się podstępu, zebrał wszystkich zdrowych i chorych z Nuestra Señora i ruszył w stronę El Tocuyo, gdzie przebywał Juan de Carvajal. Hiszpan podstępnie przejął uprawnienia Felipe de Utre: nie dość, że przywłaszczył sobie tytuł gubernatora, to jeszcze niezgodnie $z$ prawem dokonał fundacji miasta El Tocuyo, zatem starcie było nieuniknione. Utre zatrzymał się w dolinie Barquisimeto, wyczekując ruchu przeciwnika. Przyjął zaproszenie Carvajala i zapewnienia o jego przyjaźni i życzliwości i także osiadł ze swoim oddziałem w El Tocuyo. W czasie uczty obie strony skakały sobie do gardeł. Utre miał przewagę liczebna, ale postanowił się wycofać. Oddalił się na cztery ligi, zabierając broń i konie niedoszłego gubernatora. 
Wcześniej zaś musiał powstrzymać zapędy Bartolomé Welsera, gotowego przebić rapierem Carvajala, zatem młody Niemiec zadowolił się uderzeniem Hiszpana tępym końcem lancy, zwalając go w błoto. Carvajal, stary wyga, bardziej podstępny i sprytny od obu Niemców, pozorował polubowne rozwiązanie konfliktu. Do obozu Felipe de Utre wysłał misję pokojowa, złożoną z kapelana wyprawy - ojca Frutos de Tudela oraz Juana de Villegas i Niemca Melchora Grubel ${ }^{18}$, który w prowincji sprawował pieczę nad interesami Welserów. Przekonali oni Felipe de Utre o pokojowych zamiarach Carvajala, a nadto skłonili do oddania rynsztunku i koni. Wymusili także na Niemcu powrót do Coro $z$ nielicznymi żołnierzami, którzy chcieliby mu towarzyszyć. Ten zaufał swojemu adwersarzowi i ruszył w droge powrotna do Coro.

Szli w rozsypce, bezwładna masą. Rozbili obóz u stóp Sierra de Coro. O zmierzchu nadciągnał Carvajal. Ufni w porozumienie Niemcy się nie bronili. Carvajal rozkazał zaufanemu Murzynowi, by związał ręce obu Niemcom, Felipe de Utre i Bartolomé Welserowi, i ścią maczeta ich głowy, a nadto dwóm innym Hiszpanom, którzy im sprzyjali: kapitanowi Pedro Romero i Gregorio de Plasencia.

„A że ostrze tego narzędzia było stępione, służyło bowiem innym, bardziej pospolitym celom, w długiej, męczeńskiej agonii zakończyli życie owi nieszczęśnicy, bardziej od kolejnych razów niż od cięcia ostrza, w obliczu zatwardziałości barbarzyńskiego serca tej bestii, niepomnej okrutnych okoliczności tej tyrańskiej męki; przeciwnie, wraz z Limpiasem i Sebastianem de Armacea [Amescua] rozkoszował się widokiem owej kaźni"19.

Wedle kapelana Frutos de Tudela więźniowie przed egzekucja domagali się spowiedzi, ale Carvajal był nieprzejednany. Kapelan nalegał i podniesionym głosem, zwracajac się do wszystkich obecnych, domagał się od Carvajala wypełnienia chrześcijańskiej powinności: miał on władzę nad ciałami, ale nie nad duszami, zatem musiał zezwolić na spowiedź skazańców. Tę dramatyczna scenę uwiecznił poeta-kronikarz Juan de Castellanos w swej Elegii na śmierć gubernatora Felipe de Uten: „Już pewni, że śmierć ich czeka, / O spowiedź prosza, / Lecz owa bestia ślepa / Choć nie brak tu kapłanów, / Uparcie odmawia zgody"20. Jedyne, co uzyskał

18 Kronikarze określali go jako Niemca, ale w istocie był Helwetem i prawdopodobnie pochodził z Sankt Gallen.

${ }^{19} \mathrm{~J}$. de Oviedo y Baños, op. cit., s. 139.

${ }^{20} \mathrm{~J}$. de Castellanos, op. cit., s. 344. 
kapelan, to pogrzebanie ciał i pozostawienie epitafium na miejscu pochówku.

Niektórzy świadkowie zaprzeczali temu, że egzekucja odbyła się na placu w El Tocuyo. Ponoć stało się to daleko za miastem, na pustkowiu. Tak czy owak, w roku 1549 ciała zostały odgrzebane i zabrane do Coro przez florentyńskiego kupca Galeotta Cey i pochowane w katedrze w Coro. Spoczywaja tam nadal.

Jakże żałosny był koniec Carvajala: przywiązany do końskiego ogona, „wleczony przez cała osadę, na oczach wszystkich, a potem powieszony na tej samej ceibie, którą przeznaczył dla innych"21.

$$
* * *
$$

\section{Relacja Galeotta Cey o egzekucji Niemców pod E1 Tocuyo ${ }^{22}$}

„Był już styczeń, gdy przemierzaliśmy te góry o osiem lig odległe [od El Tocuyo], szukając prowiantu i rabując kukurydzę, i usłyszeliśmy od Indian wieść, że na równinie 20 lig stąd sa jacyś chrześcijanie. Przekazaliśmy tę nowinę gubernatorowi [Juanowi de Carvajal], który wstrzymał marsz, by wybadać, kim sa tamci, zaś pod koniec lutego dotarł do naszej osady Bartolomeo, syn Bartolomé Welsera, $z$ dwudziestoma towarzyszami, a wszyscy w łachmanach, a mieli ze soba tylko dwa konie. Wysłał ich Felipe de Hutten, dowódca tamtych, by $z$ portu w Coro sprowadzili ludzi albo ściagnęli ich $z$ Santo Domingo i powiedli do miejsca, które zasiedliliśmy, albo tam, gdzie on będzie ich oczekiwał, bowiem został w tyle $z$ pozostałymi dwudziestoma Chrześcijanami i sześcioma końmi, bo tyle się ostało ze 130 ludzi i 150 koni, którzy wyruszyli cztery i pół roku wcześniej

${ }^{21}$ L.F. de Piedrahita, op. cit., s. 419.

${ }^{22}$ Galeotto Cey (Cei) urodził się 29 IV 1513 r. we Florencji. Młodość spędził, jeżdżąc po Europie, głównie południowej Francji, jako kupiec. W latach 1532-1537 przebywał w Sewilli, trudniąc się handlem, ale bez specjalnego powodzenia. Chłonął tam opowieści o bogactwach Nowego Świata, a że pochodził z kupieckiej rodziny i miał pragmatyczne podejście do życia, bardziej niż złoto, srebro, perły i szmaragdy porywała go wizja fortuny, którą mogło mu przynieść sprowadzenie do Ameryki europejskich towarów. Postanowił zatem szukać szczęścia w Nowym Świecie, najpierw w Wenezueli, a potem w Nowym Królestwie Grenady. Spędził tam 14 lat. Niewiele postaci związanych $z$ dziejami tego regionu łaczyło w sobie tyle ról i profesji, co Cey: był osadnikiem, kupcem, odkrywca, konkwistadorem i skotnikiem. Spisał swoje wspomnienia w Podróży i opisaniu Indii 1539-1553 po powrocie do rodzinnej Florencji i ukończył je około 1569 r., 10 lat przed swoja śmiercią. Cytat na podstawie wydania: G. Cey, Viaje y descripción de las Indias 1539-1553, Caracas 1995, s. 62-66. 
na wyprawę. Gdy Bartolomé Welser ze swoimi ludźmi dotarł do naszej osady, zadziwił się obecnością innego gubernatora na tych ziemiach i poprosił o zgodę, by wrócić ze swoim kapitanem albo też kontynuować wędrówkę do portu, ale nie dostał na to przyzwolenia za sprawa złej woli naszego gubernatora, bo wiedział on, że gdy ta wiadomość dotrze do Santo Domingo, zostanie pozbawiony swojej rangi, która ponownie będzie przekazana tamtemu, tak jak to było postanowione przez Radę Hiszpanii [Indii]. A gdyby zezwolił mu [Bartolomé Welserowi] na powrót, mogliby inną droga dotrzeć do portu. Dlatego odmówił licencji i zatrzymał go, i niezwłocznie wysłał swego kapitana $z$ sześćdziesięcioma ludźmi, by odszukali i sprowadzili tu owego Felipe de Hutten. Wyruszyli tamci i częściowo za namową, częściowo siłą, przyprowadzili go, co miało miejsce w Wielką Sobotę, roku 1546, która wówczas przypadała na 24 albo 25 kwietnia, a podczas dwóch dni Świąt wielu okazywało swoje niezadowolenie, pomstując na gubernatora naszego i na gubernatora tamtych, a nie cieszył się on estyma, i chociaż przestrzegałem go, by nie ufał buntownikom, bo napytaja mu biedy, ale on nie chciał mnie słuchać, chociaż byliśmy od dawna zaprzyjaźnieni, a znał mnie jeszcze $z$ Santo Domingo, dokąd Welser przybył z Hiszpanii, a ja wynająem mu konie i statek, na którym przybył do rzeczonej prowincji. Rozmówiłem się także $z$ naszym gubernatorem i wypomniałem mu, jak bardzo szemrza przeciw niemu jego ludzie, a zatrzymanie tamtych przy nas tylko wyjdzie im na korzyść i lepiej pozwolić im pójść swoja droga i zostawić im te ziemie, i doradziłem mu, żeby potem, $z$ końcem października - $z$ wielkimi stadami bydła, które posiada, $z$ czego połowę zrabował, a za pieniądze, które ma, mógłby dokupić jeszcze więcej - wyruszył ze swymi kompanami do Nowego Królestwa Grenady, gdzie zarobiłby piętnaście albo i dwadzieścia tysięcy ducados. On jednak nie posłuchał mnie i wolał ich uwięzić. Tamci jednak byli uprzedzeni o tych zamiarach i tak, trzeciego dnia Swiąt, Felipe de Hutten, Bartolomé Welser i wszyscy ludzie, którzy z nimi przybyli, $z$ bronia w ręku wyszli na plac, gdzie był gubernator i tam układnie i grzecznie poprosili go o przyzwolenie, ale ten w grubiańskich słowach odmówił i wówczas wszyscy chwycili za broń. Zagrzmiały werble, wszyscy dosiedli koni, a gubernator wycofał się z placu. Doszłoby do potyczki, gdyby nie Welser, człowiek energiczny, który dopadł Carvajala, naszego gubernatora, a ten był znacznie lepiej uzbrojony i był konno, a mimo to, $z$ wrodzonego tchórzostwa, umknał $\mathrm{z}$ pola walki. 
Obie strony rozeszły się do swoich obozów, jedni planując opuszczenie osady, drudzy przemyśliwali o uwięzieniu przeciwników. Gdy nastała noc, Felipe de Hutten i jego ludzie zabrali swój ekwipunek, a nadto kilka koni $z$ naszego obozu i opuścili osadę, kierując się ku odległej o pięć lig równinie, zwanej Quíbor. Tam natknęli się na dwudziestu ludzi, zbrojnych i jezdnych, $z$ naszego obozu, który powracali $z$ wyprawy po kukurydzę. Zatrzymali ich, rozbroili i pozbawili koni, ale niczego więcej nie zabrali.

Wielkie zamieszanie panowało owej nocy, a następnego dnia nasz gubernator nie szczędził słów, aby przekonać ludzi, by poszli za nim. Widzac jednak powszechne niezadowolenie, zmienił zamiary i polecił swemu kapitanowi, księdzu i pewnemu Szwajcarowi, Melchorowi Gruhelowi [Grubelowi], którzy mu towarzyszyli, by paktowali $z$ tamtymi. Tak też się stało i uzgodniono, że nikt nie będzie wypominał nikomu przeszłości, ani nie wniesie żadnych oskarżeń, zaś tamci mają uwolnić wszystkich więźniów, oddać broń i konie, a kto pragnie odejść albo zostać, ma wolną rękę w tej kwestii, a nasz gubernator, $z$ wszystkimi znaczniejszymi oficerami ze swego obozu, zobowiązał się na piśmie, pod groźbą kary i zarzutu zdrady, że nie będzie tamtych ścigał, ani nie ucieknie się do przemocy, i pozwoli im odejść tam, gdzie chca i tak właśnie postanowiono.

Po czterech dniach, które tamci spędzili na równinie, za zgodą gubernatora odwiedziliśmy ich obóz, ja zaś ponownie przestrzegałem ich, by mieli się na baczności i czym prędzej opuścili to miejsce, i aby byli świadomi, że żadna obietnica nie będzie dotrzymana, ale oni nie dali temu wiary. Odjechali w początkach maja, my zaś powróciliśmy do osady, z siedmioma czy ośmioma od nich, którzy przyłączyli się do nas, a do tamtych przeszło tylko dwóch $z$ naszego obozu i tak było ich trzydziestu $z$ ośmioma końmi. Gdy wróciliśmy do osady, dostrzegliśmy, że obstawiono wszystkie gościńce tak, by nikt $z$ osady nie przybył do tamtych $z$ pomocą. Owej nocy na próżno starałem się odgonić złe przeczucia. O świcie zostałem uwięziony z trzema innymi towarzyszami, $z$ którymi przekonywałem tamtych o szykowanej zdradzie, aby uniemożliwić nam przyłączenie się do onych.

Zebrał gubernator wszystkich ludzi i począł wylewać żale za oszczerstwa, które na niego spadaja, i argumentować, że nie jest zobligowany do przestrzegania żadnych poczynionych $z$ tamtymi ustaleń i paktów, ale te słowa nikogo nie przekonały. Widząc to, ponownie dał wszystkim swoje wybaczenie i dowodził, że zamierzał ruszyć za tamtymi tylko po to, by wytoczyć im proces. Uwolnił mnie 
$z$ innymi $z$ więzienia i długo przekonywał, bym przeszedł na jego stronę, ale ja byłem nieugięty. Potem rozgłosił, że zamierza się udać na wyprawę i wezwał ludzi, by się do niego przyłączyli, obiecując bogate łupy i pod tym pozorem opuścił osadę, zmierzając ku równinie Quíbor. Ruszył ze wszystkimi swoimi ludźmi, a tym, co zostali w osadzie, pod kara śmierci zabronił opuszczania jej aż do swego powrotu. W nocy nakazał zabrać broń i konie, $z$ wyjątkiem kilku, i wyruszyliśmy śladem tamtych i nic już nie mogło go powstrzymać, a Bóg mi świadkiem, że przewidziałem to, co miało się wydarzyć.

$\mathrm{W}$ połowie maja dopadł ich w wawozie wypełnionym ogromnymi głazami, w górach odległych o 40 lig od naszej osady. O zmierzchu uwięził ich, nie napotykając na żaden opór i wkrótce rozkazał ściąć dwóch chrześcijan $z$ obozu tamtych; jeden pochodził $z$ Wysp Kanaryjskich i zwał się Juan Romero, a drugi był z Hiszpanii i zwał się Gregorio de Plasencia. Zaraz potem uczynił to samo z Bartolomé Welserem i Felipe de Hutten, nie bacząc na to, że ten ostatni był blisko skoligacony $z$ domem Austrii i nawet nie dał im czasu, by się wyspowiadali, chociaż był $z$ nimi ksiądz, a rzecz to zgoła sprzeczna $z$ obyczajem Hiszpanów, którzy sa bardzo katoliccy z pozoru, ale gniew każe im zapomnieć o swej wierze.

Gdy to uczynił, zakuł w kajdany co znaczniejsze osoby i zabrał ze soba, a pozostałym pozwolił odejść, chociaż część z nich już wcześniej uciekła, owe ciała kazał pochować w pobliskiej, niewielkiej jamie, po czym niezwłocznie wrócił do osady, gdzie wiele osób uwięził i długo deliberował, czy uciąć głowy, czy powiesić na gałęzi tuzin $z$ nas. Mnie próbował uśmiercić w nocy, potajemnie, na pryczy, ale uprzedzono mnie o tych zamiarach i nie spałem $\mathrm{w}$ domu, tylko w zagonie kukurydzy albo w jakimś lesie i wielokrotnie noca wchodzili do mego domu, i tak żyłem przez cztery miesiące. Za dnia nie ośmielali się mnie napastować, chociaż często opuszczałem osadę sam, ale nie lękałem się o swoje życie, bo miałem rączego konia i dobrze wiedziałem, kogo się wystrzegać: osoby, która przemawiała do mnie każdego dnia, z przymilnym uśmiechem. On tymczasem zajmował się procesem przeciwko więźniom i zamordowanym, aby w końcu wydać werdykt skazujacy więźniów na służbę Królowi i oskarżający martwych o zdradę i kradzieże. W tym samym czasie wysłał oddział na miesięczny rekonesans w pewne góry, ci zaś po przebyciu 20 lig powrócili $z$ niczym. I tak nadszedł sierpień i postanowił przepędzić bydło swoje i swoich wrogów, z których część zdążył skazać i gotów był uśmiercić ośmiu ludzi, którzy byli wobec 
niego najbardziej nieprzejednani, przejmując cały ich majątek, i z tymi wszystkimi dobrami udać się do Nowego Królestwa Grenady i tam je spieniężyć, i pewnie by tak zrobił, gdyby nie był tak leniwy, próżny i niezdecydowany. A nadto pora roku nie sprzyjała jego planom, bowiem nastała pora deszczowa, a on nie lubił przeciwności losu, a poza tym powątpiewał w lojalność swoich ludzi, którzy nie mogli mu darować tego, że mimo obietnic wszystkie zdobyte dobra zatrzymał dla siebie.

Zdarzyło się rankiem 27 sierpnia, że z czterema towarzyszami poprosiłem go o zgodę na polowanie na równinie Quibor, a potem na wyprawę do portu, bo lepiej było w drodze zginąć $z$ ręki Indian, niż nadstawiać kark pod jego topór, ale Bóg sprawił, że o świcie przyjechał juez de residencia [sędzia audytor], który przybył z Hiszpanii do portu w Coro, gdzie zastały go wieści o pomordowanych, przyniesione przez tych, którym udało się zbiec, i tych, którym [Carvajal] pozwolił odejść. Wyruszył niezwłocznie sędzia z sześćdziesięcioma ludźmi, w większości należących wcześniej do oddziału Felipe de Hutten, i dotarł na miejsce 27 sierpnia. Chociaż Indianie zapowiadali, że nadciągaja chrześcijanie, nasz gubernator nie dał temu wiary i tak pozwolił się zaskoczyć i aresztować razem ze swoimi kompanami. W jego pugilaresie znaleziono sporządzona jego ręką listę ośmiu osób, które zamierzał uśmiercić; ja figurowałem na drugim miejscu. Kiedy zapytałem go o to, odrzekł, że mnie nie lubi, bo zawsze mówiłem mu prawdę prosto w oczy, a nadto, jeszcze w Santo Domingo, $z$ powodu sprawy $z$ pewna dama, w czym i on brał udział, i tak poznałem na własnej skórze, czym kończy się bezstronność, bowiem gdybym tylko zechciał, niechybnie by go zabito, a nadto ja nie wplątałbym się w rozmaite przygody, których doświadczyłem, jako że gdy ktoś zamierza wyplątać się z jakieś opresji, wplątuje się w jeszcze gorszą. Gdy był w więzieniu, znaleziono owa rzecz, a także pismo $z$ pieczęcią królewską, które sfałszował, przyznając sobie przywileje i funkcje, które mu się nie należały. Stanął przed sądem i skazano go na szubienicę, dokąd go zawleczono przy dźwięku trąb, po czym martwym przywrócono honor i dobra w liczbie czterech szmatek i dwóch koni, jego wspólnikom skonfiskowano majątek, który w połowie został się w gubernatorstwie, a w połowie został wywieziony". 
Dnia 27 sierpnia 1546 r. odbyło się przesłuchanie Juana de Carvajal w juicio de residencia, zarządzonym przez Real Audiencia w Santo Domingo. Oskarżono go o bezprawne przywłaszczenie sobie tytułu gubernatora i naczelnego wodza (capitán general), przez co „dopuścił się czynów niegodziwych i nikczemnych, postępków tyrańskich i okrutnych zarówno wobec chrześcijan, jak i Indian, poddanych JW i żyjacych w pokoju" ${ }^{23}$. Carvajal musiał odpowiedzieć na 109 pytań dotyczących wydarzeń, które rozegrały się między Coro a El Tocuyo. W mowie obrończej oskarżył Pedra de Limpias i Sebastiana de Amescua, że to oni namówili go i skłonili do zbrodni. Oskarżył też Felipe de Utre i jego ludzi o mordowanie tubylców i o bunt przeciw królowi. Sędzia i gubernator Pérez de Tolosa ogłosił wyrok 16 września: „Skazujemy oskarżonego Juana de Carvajal na wywleczenie $z$ więzienia publicznego; przywiazany do końskiego ogona przez plac miejski będzie wleczony do miejsca, gdzie stoi szafot i tam zostanie powieszony za szyję na sznurze skręconym $z$ ostnicy lub konopi tak, że umrze śmiercią naturalną i niechaj nikt nie ośmieli się, pod kara śmierci, odciąć go bez mojego, Gubernatora, zezwolenia" ${ }^{24}$.

Dopiero pod szubienica Carvajal wyznał skruchę w obecności skryby i zadeklarował, że „tylko on ponosi winę za śmierć Felipe de Hutten, Bartolomé Belzara, Gregoria de Plasencia i Diega Romero i w obliczu kary Bożej wyznaje, że tym czynem obraził Pana Naszego i przyjmuje ten wyrok ze spokojem, jako zadośćuczynienie za zbrodnie i występki, które popełnił przeciw Bogu, czyny wielkiego grzesznika i złego chrześcijanina”25.

$$
* * *
$$

\section{Królewska ceduła nakazująca osądzenie winnych zamordowania Felipe de Utre i Bartolomé Welsera (1548) ${ }^{26}$}

„Król. - Przewodniczacy i członkowie naszej Rady Indii. - Od J. eks. biskupa Aystet [Aystetten] i Guillerma de Huten, jego brata

${ }^{23}$ Juicios de residencia en la provincia de Venezuela, t. I, wyd. M. Ponce de Behrens, D. Rengifo, L. Vaccari de Venturini, Caracas 1977, cyt za: El Libro del Oro de Venezuela, Caracas 2010, s. 24.

${ }^{24}$ Ibidem.

${ }^{25}$ Ibidem.

${ }^{26}$ Real cédula mandando..., s. 277-280. 
i Bartolomé i Antonia Belzeres, otrzymaliśmy wieści, że Phelipe de Huten, brat rzeczonego biskupa i Guillerma, $z$ nasza licencja przybył do prowincji Wenezuela i Cabo de la Vela $z$ armada pod dowództwem gubernatora Jorge Hohermuta, etc. Przybywszy i na ląd wysiadłszy w owej prowincji, rzeczony gubernator dokonał odkryć i tamże zmarł, i z uwagi na śmierć i koniec jego Audiencia, rezydujacca na wyspie Santo Domingo, wyznaczyła na naczelnego wodza [capitán general] owej prowincji rzeczonego Philipe de Huten, który wyruszył do interioru, co zabrało mu pięć lat i odkrył liczne i bogate ziemie, i prowincje, etc. Roku zeszłego, 46, powrócił rzeczony Philipe, by zdać relację ze swych odkryć i przekonał się, że rok wcześniej oidores [sędziowie] Audiencji, nie wiedząc, czy jest on żywy czy też martwy, ani nie mając od Belzerów żadnych nominacji ani zleceń, wybrali na gubernatora i naczelnego wodza owej prowincji Juana de Carvajal, który wiedząc, że Philipe de Huten przybył z łupami, odkrywszy bogate ziemie i prowincje, $z$ przewrotna niegodziwościa i chciwością uwięził rzeczonego Phelipe de Huten i z nim młodego Bartolomé Belzera, Alonsa Romero i Gregoria de Plasencia, a potem wszystkich ich bez dania racji kazał ściąć, aby zagarnać i ukraść to, co Phelipe de Huten przywiódł ze soba i aby to jemu przypadły zasługi owych odkryć i chociaż licencjat Tolosa, juez de residencia rzeczonej prowincji, przeprowadził śledztwo i wywiedział się o tej zbrodni, i po upewnieniu się, że została ona popełniona, pochwycił i powiesił rzeczonego Juana de Carvajal, ogłaszając Phelipe de Huten i młodego Bartolomé Belzera za lojalnych wasali i nasze sługi, nie osądził pozostałych uczestników owej niegodziwości i zdrady ani nie dokonał sekwestracji dóbr należących uprzednio do Phelipe de Huten i młodego Bartolomé Belzera i pozostałych dwóch, którzy $z$ nimi zginęli, i nie przekazał owych dóbr prawowitym spadkobiercom, co winien był uczynić, zatem nakazujemy, by sprawiedliwości stało się zadość, nie tylko wobec rzeczonego Juana de Carvajal, ale nadto wobec wszystkich odpowiedzialnych za tę zbrodnię, i aby winni zostali uwięzieni i dla przykładu, zgodnie $z$ prawem, ukarani i nadto nakazuje się licencjatowi Tolosie i innym odpowiedzialnym osobom, by złoto, srebro, kosztowności i wszelakie inne dobra należące do Phelipe de Huten, młodego Bartolomé Belzera, Alonsa Romero i Gregoria de Plasencia zostały zebrane i oszacowane, i przekazane naszym urzędnikom $z$ Casa de la Contratación, rezydującym w mieście Sewilii i tam zwrócone prawowitym właścicielom. Nakazujemy nadto, by jak najszybciej i najsumienniej dokonany 
został akt sprawiedliwości, tak aby wszyscy, którzy okazali się w tej sprawie winni, zostali osądzeni i ukarani [...].

Nakazujemy nadto, zgodnie $z$ życzeniem rzeczonych Belzares, jako że regularnie uczestniczą w posiedzeniach Rady, co tyczy spraw owej prowincji Wenezueli, by ich interesy były respektowane i w owych sprawach byli uprzywilejowani, jako że poczynili znaczne wydatki, by wysłać tam kolejne armady, nie majac dotąd $z$ tego żadnych korzyści, zaczem $z$ tego powodu i wobec przysług, jakie nam oddawali i nadal oddaja, przychylamy się do ich prośby [...]. 11 lutego 1548".

$$
* * *
$$

Zanim król wydał powyższą cedułę, gubernator i sędzia Juan Pérez de Tolosa zmarł $z$ powodu wysokiej gorączki w drodze do Cabo de la Vela, a wcześniej bezskutecznie poszukiwał Eldorado na bezdrożach północno-zachodniej Wenezueli. Dom bankierski Welserów już w 1546 r. został oskarżony przez Radę Indii o naruszenie koncesji i wkrótce stracił wszystkie swoje dobra i przywileje w prowincji. Po egzekucji Juana de Carvajal okazało się, że po latach wypraw po złoto dorobił się tylko długów: „Carvajal skazany został na utratę wszystkich swych dóbr na rzecz Izby JW., a były one tak nieliczne, że w niczym nie zrównoważyły długów"27. Po Felipe de Utre i jego towarzyszu broni, młodym Bartolomé Welserze, pozostało nagrobne epitafium: „Felipe de Uten martwy / Spoczał w tej surowej ziemi, / I podobny smutny los / Spotkał Bartolomé Belzara / W tym samym grobie pogrzebany"28.

\section{BIBLIOGRAFIA}

\section{ŹRóDEA DRUKOWANE}

Aguado P. de, Historia de Venezuela, Madrid 1918.

Alemanes en las regiones equinocciales, wyd. J. Ángel Rodríguez, Caracas 1999.

Castellanos J. de, Elegias de varones ilustres de Indias, [w:] Obras de Juan de Castellanos, Caracas 1930.

Cey G., Viaje y descripción de las Indias 1539-1553, Caracas 1995.

El Libro del Oro de Venezuela, Caracas 2010.

${ }^{27}$ Cartas dirigidas al Rey por el Licenciado Juan Pérez de Tolosa..., s. 224.

${ }^{28}$ J. de Castellanos, op. cit., s. 345. 
Hermanos P.L., Editorial Sur América, Caracas 1930.

Historia de la conquista y población de la provincia de Venezuela escrita por Dr. José de Oviedo y Baños, Madrid 1885.

Juicios de residencia en la provincia de Venezuela, wyd. M. Ponce de Behrens, D. Rengifo, L. Vaccari de Venturini, t. I, Caracas 1977.

Oviedo G.F. de, Historia general y natural de las Indias, islas y tierra-firme del mar océano, Madrid 1852.

Oviedo y Baños J. de, Historia de la conquista y población de la Provincia de Venezuela, Caracas 2004.

Piedrahita L.F. de, Historia general de las conquistas del Nuevo Reyno de Granada, Amberes 1688.

Simón P., Noticias historiales de las conquistas de Tierra Firme en las Indias Occidentales, Bogotá 1882.

Simón P., Noticias historiales de Venezuela, t. II, Caracas 1992.

\section{OpRacowania}

Arciniegas G., Felipe von Hutten, o la ilusión de 'El Dorado, [w:] idem, América, tierra firme y otros ensayos, Caracas 1990. 